\title{
Assessment model of debris flow hazard along the Tianshan Highway
}

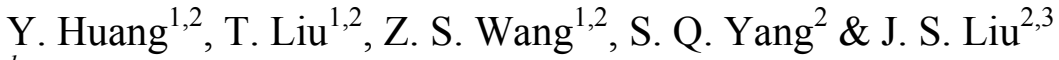 \\ ${ }^{1}$ Xinjiang Traffic and Highway Institute of Science, Urumqi, China \\ ${ }^{2}$ Xinjiang Agriculture University, Urumqi, China \\ ${ }^{3}$ Xinjiang Architectural Design Institute, Urumqi, China
}

\begin{abstract}
Debris Flow Hazard Assessment along the Tianshan Highway was carried out based on an established model. The assessment results indicated impacts of debris flow hazards to the highway and supplied a quantitative index with highway construction designs and protection in the debris flow affected area. The model formula can be shown as: $\mathrm{S}=\mathrm{K}_{1} \mathrm{~K}_{2}$; here $\mathrm{S}$ is highway debris flow hazard degree, $K_{1}$ is debris flow hazard degree $\left(0 \leq K_{1} \leq 1\right), K_{2}$ is highway damage degree $\left(0 \leq K_{2} \leq 1\right)$. Index $K_{1}$ as well as $K_{2}$ are obtained with quantitative calculations respectively. This model has been verified based on research on highway debris flow in the Tianshan Mountain area of Xinjiang in China.

Keywords: highway, debris flow, hazard degree, assessment model.
\end{abstract}

\section{The idea of highway debris flow hazard degree assessment model}

The debris flow in the Chinese Xinjiang's Tianshan mountainous area is one kind of serious natural disaster, which can interrupt the transportation on road, destroy the highway facilities, even create serious traffic accidents frequently [1].

Current domestic and foreign debris flow risk factor assessment models only can appraise debris flow gully to the natural degree and are unable to evaluate the road safety rate. In order to appraise the debris flow effectively to the highway harm degree, meet quantitative factors [2] and instruct the highway design and maintenance, we set up the following highway debris flow hazard degree assessment model.

$$
\mathrm{S}=\mathrm{K}_{1} \mathrm{~K}_{2}
$$


where $\mathrm{S}=$ the highway debris flow hazard degree and $\mathrm{K}_{1}=$ the debris flow hazard degree and $\mathrm{K}_{2}=$ the highway damage degree.

The model meaning is that debris flow hazard degree $\left(\mathrm{K}_{1}\right)$ multiplying the highway damage degree $\left(\mathrm{K}_{2}\right)$ equals the highway debris flow hazard degree, namely $\mathrm{S}(0 \leq \mathrm{S} \leq 1)$.

\section{The highway debris flow hazard degree (K1) of the Tianshan area}

The debris flow hazard degree $\left(\mathrm{K}_{1}\right)$ refers to expert investigation method [3] and debris flow hazardous factor gray connection fundamental research [4], screens from more than 20 factors and determines 9 hazardous factors [4-6], i.e. $\mathrm{GL}_{1}$, $\mathrm{GL}_{2}, \mathrm{Gs}_{1}, \mathrm{Gs}_{2}, \mathrm{Gs}_{3}, \mathrm{Gs}_{4}, \mathrm{Gs}_{5}, \mathrm{Gs}_{6}, \mathrm{Gs}_{7}$ (see Table 1) respectively.

Table 1: $\quad$ Weighted value and weighted rate of hazardous factor $\operatorname{In} \mathrm{K}_{1}$.

\begin{tabular}{|c|c|c|c|c|c|c|c|c|c|}
\hline $\begin{array}{c}\text { Hazardous } \\
\text { factor }\end{array}$ & $\mathrm{S}_{5}$ & $\mathrm{~S}_{7}$ & $\mathrm{~S}_{6}$ & $\mathrm{~S}_{3}$ & $\mathrm{~S}_{2}$ & $\mathrm{~S}_{4}$ & $\mathrm{~S}_{1}$ & $\mathrm{~L}_{1}$ & $\mathrm{~L}_{2}$ \\
\hline $\begin{array}{c}\text { Weighted } \\
\text { value }\end{array}$ & 1 & 3 & 4 & 5 & 6 & 7 & 8 & 16 & 16 \\
\hline $\begin{array}{c}\text { Weighted } \\
\text { rate }\end{array}$ & 0.0152 & 0.0455 & 0.0606 & 0.0758 & 0.0909 & 0.1061 & 0.1212 & 0.2424 & 0.2424 \\
\hline
\end{tabular}

From this table, we see that 2 main hazardous factors $\left(\mathrm{GL}_{1}, \mathrm{GL}_{2}\right)$ occupy $48.48 \%$ and 7 secondary hazardous factors account for $51.52 \%$.

Thus there is the debris flow hazard degree formula:

$$
\begin{gathered}
\mathrm{K}_{1}=0.2424 \mathrm{GL}_{1}+0.2424 \mathrm{GL}_{2}+0.1212 \mathrm{Gs}_{1}+0.0909 \mathrm{Gs}_{2}+0.0758 \mathrm{Gs}_{3} \\
+0.1061 \mathrm{Gs}_{4}+0.0152 \mathrm{Gs}_{5}+0.0606 \mathrm{Gs}_{6}+0.0455 \mathrm{Gs}_{7}
\end{gathered}
$$

where $\mathrm{K}_{1}$ is the debris flow hazard degree $\left(0 \leq \mathrm{K}_{1} \leq 1\right), \mathrm{G}_{L_{1}}$ is the possible maximum debris flow evaluation per time, $\mathrm{GL}_{2}$ is the debris flow frequency evaluation, $\mathrm{Gs}_{1}$ is the drainage area evaluation, $\mathrm{Gs}_{2}$ is the main ditch length evaluation, $\mathrm{Gs}_{3}$ is maximum relative height evaluation, $\mathrm{Gs}_{4}$ is the basin cutting density evaluation, $\mathrm{Gs}_{5}$ is the main ditch bed curving coefficient evaluation, $\mathrm{Gs}_{6}$ is the silt military supplies segment size ratio evaluation and $\mathrm{Gs}_{7}$ the water source military supplies quantity evaluation.

Table 2 shows the multiple coefficient of correlation evaluation standard.

\section{The highway damage degree (K2) of the Tianshan debris flow area}

In order to better limit debris flow to the harmful degree on highway, we ideally suppose the roadbed height for zero (crawling in the mud-rock flow area through the time) and do not suppose structures and arch of bridge. It is advantageous for getting the damage ratio. 
Table 2: Tianshan highway debris flow hazardous factor rank and evaluation.

\begin{tabular}{|c|c|c|c|c|c|c|c|}
\hline $\begin{array}{l}\text { hazardous } \\
\text { factor rank }\end{array}$ & (1) & (2) & (3) & (4) & (5) & (6) & Unit \\
\hline $\mathrm{L}_{1}$ & $\leq 0.1$ & $(0.1) \sim 1$ & (1) $\sim 10$ & $\begin{array}{c}(10) \sim ~ \\
50\end{array}$ & $\begin{array}{l}(50) \sim \\
(100)\end{array}$ & $\geq 100$ & \multirow{2}{*}{$10^{4} \mathrm{~m}^{3}$} \\
\hline $\mathrm{GL}_{1}$ & 0.0 & 0.2 & 0.4 & 0.6 & 0.8 & 1.0 & \\
\hline $\mathrm{L}_{2}$ & $\leq 5$ & $(5) \sim 10$ & $\begin{array}{c}(10) \sim \\
20\end{array}$ & $\begin{array}{c}(20) \sim \\
50\end{array}$ & $\begin{array}{l}(50) \sim \\
(100)\end{array}$ & $\geq 100$ & \multirow{2}{*}{$\%$} \\
\hline $\mathrm{GL}_{2}$ & 0.0 & 0.2 & 0.4 & 0.6 & 0.8 & 1.0 & \\
\hline $\mathrm{s}_{1}$ & $\leq 0.1$ & $(0.1) \sim 1$ & $(1) \sim 5$ & (5) $\sim 10$ & $(10) \sim(30)$ & $\begin{array}{c}(30) \sim \\
(50)\end{array}$ & \multirow{2}{*}{$\mathrm{Km}^{2}$} \\
\hline $\mathrm{Gs}_{1}$ & 0.0 & 0.2 & 0.4 & 0.6 & 0.8 & 1.0 & \\
\hline $\mathrm{s}_{2}$ & $\leq 0.1$ & $(0.1) \sim 1$ & (1) $\sim 2$ & $(2) \sim 5$ & $(5) \sim(10)$ & $\geq 10$ & \multirow{2}{*}{$\mathrm{Km}$} \\
\hline $\mathrm{Gs}_{2}$ & 0.0 & 0.2 & 0.4 & 0.6 & 0.8 & 1.0 & \\
\hline $\mathrm{S}_{3}$ & $\leq 0.1$ & $\begin{array}{c}(0.1) \sim \\
0.5\end{array}$ & $\begin{array}{c}(0.5) \sim \\
0.7 \\
\end{array}$ & $\begin{array}{c}(0.7) \sim \\
1.0\end{array}$ & $\begin{array}{c}(1.0) \sim \\
(1.5)\end{array}$ & $\geq 1.5$ & \multirow{2}{*}{$\mathrm{Km}$} \\
\hline $\mathrm{Gs}_{3}$ & 0.0 & 0.2 & 0.4 & 0.6 & 0.8 & 1.0 & \\
\hline $\mathrm{S}_{4}$ & $\leq 0.1$ & $(0.1) \sim 1$ & $(1) \sim 5$ & $(5) \sim 10$ & $(10) \sim(20)$ & $\geq 20$ & \multirow[t]{2}{*}{$\mathrm{Km}_{2} / \mathrm{km}$} \\
\hline $\mathrm{Gs}_{4}$ & 0.0 & 0.2 & 0.4 & 0.6 & 0.8 & 1.0 & \\
\hline $\mathrm{S}_{5}$ & $\leq 1.1$ & $\begin{array}{c}(1.1) \sim \\
1.2 \\
\end{array}$ & $\begin{array}{c}(1.2) \sim \\
1.3 \\
\end{array}$ & $\begin{array}{c}(1.3) \sim \\
1.4 \\
\end{array}$ & $\begin{array}{c}(1.4) \sim \\
(1.5)\end{array}$ & $\geq 1.5$ & \multirow{2}{*}{$\begin{array}{l}\text { Non-unit } \\
\text { parameter }\end{array}$} \\
\hline $\mathrm{Gs}_{5}$ & 0.0 & 0.2 & 0.4 & 0.6 & 0.8 & 1.0 & \\
\hline $\mathrm{S}_{6}$ & $\leq 0.1$ & $\begin{array}{c}(0.1) \sim \\
0.2\end{array}$ & $\begin{array}{c}(0.2) \sim \\
0.3\end{array}$ & $\begin{array}{c}(0.3) \sim \\
0.4\end{array}$ & $\begin{array}{c}(0.4) \sim \\
(0.6)\end{array}$ & $\geq 0.6$ & \multirow{2}{*}{$\begin{array}{l}\text { Non-unit } \\
\text { parameter }\end{array}$} \\
\hline $\mathrm{Gs}_{6}$ & 0.0 & 0.2 & 0.4 & 0.6 & 0.8 & 1.0 & \\
\hline $\mathrm{S}_{7}$ & $\leq 0.1$ & $(0.1) \sim 1$ & (1) $\sim 10$ & $\begin{array}{c}(10) \sim ~ \\
50\end{array}$ & $\begin{array}{l}(50) \sim \\
(100)\end{array}$ & $\geq 100$ & \multirow{2}{*}{$\mathrm{m}^{3} / \mathrm{s}$} \\
\hline $\mathrm{Gs}_{7}$ & 0.0 & 0.2 & 0.4 & 0.6 & 0.8 & 1.0 & \\
\hline
\end{tabular}

Under the above supposed conditions, there are two factors deciding $\mathrm{K}_{2}$ : the debris flow harm highway length $\left(\mathrm{L}_{\mathrm{S}}\right)$ and the average debris flow covered in silt pavement thickness $\left(\mathrm{h}_{\mathrm{S}}\right)$. According to the Tianshan highway scene investigation materials and all previous years observed statistical analysis, we discovered the above two may be the good assessment for debris flow damage on the highway. According to expert investigation method [3] findings, we establish debris flow highway damage degree model formula as follows:

$$
\mathrm{K}_{2}=0.5 \mathrm{G}_{\mathrm{s}}+0.5 \mathrm{G}_{\mathrm{s}}
$$

where $K_{2}$ is the debris flow hazard degree $\left(0 \leq K_{2} \leq 1\right), G_{L_{S}}$ is the debris flow harm highway length evaluation, $\mathrm{G}_{\mathrm{h}_{\mathrm{s}}}$ is the average debris flow covered in silt pavement thickness evaluation. The multiple coefficient of correlation evaluation standard sees Table 3 and Table 4.

This means tends to the compromise and the error relatively small. It is suitable to calculate the Tianshan debris flow area's highway damage. Whether it can be applied to other highway debris flow area, it still needs to demonstrate. 
Table 3: $\quad$ Graduation of Ls.

\begin{tabular}{|c|c|c|c|c|c|c|c|c|c|c|}
\hline $\begin{array}{c}\mathrm{Ls} \\
(\mathrm{m})\end{array}$ & $0 \sim$ & $10 \sim$ & $20 \sim$ & $30 \sim$ & $50 \sim$ & $100 \sim$ & $200 \sim$ & $300 \sim$ & $400 \sim$ & $\geq$ \\
& 10 & 20 & 30 & 50 & 100 & 200 & 300 & 400 & 500 & 500 \\
\hline $\mathrm{GL}_{\mathrm{S}}$ & 0.1 & 0.2 & 0.3 & 0.4 & 0.5 & 0.6 & 0.7 & 0.8 & 0.9 & 1.0 \\
\hline
\end{tabular}

Table 4: $\quad$ Graduation of hs.

\begin{tabular}{|c|c|c|c|c|c|c|c|c|c|c|}
\hline $\mathrm{hs}$ & $0 \sim$ & $0.2 \sim$ & $0.5 \sim$ & $1.0 \sim$ & $1.5 \sim$ & $2.0 \sim$ & $3.0 \sim$ & $4.0 \sim$ & $5.0 \sim$ & $\geq 8.0$ \\
$(\mathrm{~m})$ & 0.2 & 0.5 & 1.0 & 1.5 & 2.0 & 3.0 & 4.0 & 5.0 & 8.0 & \\
\hline $\mathrm{Gh}_{\mathrm{S}}$ & 0.1 & 0.2 & 0.3 & 0.4 & 0.5 & 0.6 & 0.7 & 0.8 & 0.9 & 1.0 \\
\hline
\end{tabular}

\section{The application of highway debris flow hazard degree assessment model}

Table 5 shows the results of Tianshan highway typical debris flow hazard degree assessment through the application of the above model.

We may see from Table 5 that the examination in 11 highway debris flow gully has 10 determination results to be reliable while 1 somewhat low, but the total highway debris flow risk factor determination result has $90.9 \%$ reliability.

At the same time, we carried on the risk factor computation and the normalization in 89 typical Tianshan highway debris flow processes [7] (selecting the biggest of all predicted values as denominator and recording as 1 , other computed results are divided by this maximum value). The analysis result sees Figure 1.

Compared to the result and the thorough investigation from the chart, we discovered the model computation rate of accuracy is $89.5 \%$, which explained that the method suits in the quantitative assessment of highway debris flow harm degree in this area.

Based on the foundation, Table 6 shows the formulation Tianshan highway debris flow hazard degree assessment rank and preventing and controlling countermeasures [8].

\section{Conclusions and suggestions}

Through the above research, we obtain the conclusions as follows:

1) Tianshan highway debris flow hazard degree assessment model is suitable for this area debris flow to the road harm degree quantitative graduation assessment.

2) Through organic synthesis of the debris flow hazard degree $\left(K_{1}\right)$ and the highway damage degree $\left(\mathrm{K}_{2}\right)$, the debris flow natural characteristic and its harm function can be a whole. It may reflect objectively the harmed and threat degree of the debris flow area on the highway. 
Table 5: Tianshan highway typical debris flow gully hazard degree and determination.

\begin{tabular}{|c|c|c|c|c|}
\hline $\begin{array}{c}\text { Serial } \\
\text { number }\end{array}$ & $\begin{array}{c}\text { The } \\
\text { name of } \\
\text { debris } \\
\text { flow } \\
\text { gully }\end{array}$ & $\begin{array}{c}\text { The } \\
\text { Computed } \\
\text { result of } \\
\text { highway } \\
\text { debris flow } \\
\text { hazard } \\
\text { degree }\end{array}$ & $\begin{array}{l}\text { Debris flow harm scene } \\
\text { investigation results on } \\
\text { present situation and active } \\
\text { tendency }\end{array}$ & $\begin{array}{l}\text { Determination } \\
\text { result }\end{array}$ \\
\hline 1 & N10 & $\mathrm{S}=0.340$ & $\begin{array}{l}\text { It is covered with mud and } \\
\text { silt by } 1.0 \text { meter on the } \\
\text { highway and harmed the } \\
\text { highway section by } 50 \\
\text { meters. The harm is small and } \\
\text { the debris flow gully is in the } \\
\text { development period, but the } \\
\text { frequency is high. }\end{array}$ & Reliable \\
\hline 2 & N14 & $S=0.537$ & $\begin{array}{l}\text { It is covered with mud and } \\
\text { silt by } 1.5 \text { meters on the } \\
\text { highway and harmed the } \\
\text { highway section } 450 \text { meters. } \\
\text { The harm is highly serious } \\
\text { and the debris flow gully is in } \\
\text { the development period, but } \\
\text { the frequency is high. }\end{array}$ & Reliable \\
\hline 3 & N20 & $S=0.904$ & $\begin{array}{l}\text { It is covered with mud and } \\
\text { silt by } 20 \text { meters on the } \\
\text { highway and harmed the } \\
\text { highway section } 550 \text { meters, } \\
\text { the harm is extremely serious } \\
\text { and the debris flow gully is } \\
\text { in the development period, } \\
\text { but the frequency is low. }\end{array}$ & $\begin{array}{c}\text { Small } \\
\text { deviation }\end{array}$ \\
\hline 4 & N31 & $S=0.966$ & $\begin{array}{l}\text { It is covered with mud and } \\
\text { silt by } 15 \text { meters on the } \\
\text { highway and harmed the } \\
\text { highway section } 400 \text { meters, } \\
\text { the harm is extremely serious } \\
\text { and the debris flow gully is } \\
\text { in the development period, } \\
\text { but the frequency is low. }\end{array}$ & Reliable \\
\hline 5 & N32 & $\mathrm{S}=0.431$ & $\begin{array}{l}\text { It is covered with mud and } \\
\text { silt by } 2.2 \text { meters on the } \\
\text { highway and harmed the } \\
\text { highway section } 120 \text { meters, } \\
\text { the harm is moderate serious } \\
\text { and the debris flow gully is in } \\
\text { the development period, but } \\
\text { the frequency is high. }\end{array}$ & Reliable \\
\hline
\end{tabular}


Table 5: Continued.

\begin{tabular}{|c|c|c|c|c|}
\hline 6 & N47 & $S=0.507$ & $\begin{array}{l}\text { It is covered with mud and } \\
\text { silt by } 1.5 \text { meters on the } \\
\text { highway and harmed the } \\
\text { highway section } 300 \text { meters, } \\
\text { the harm is highly serious and } \\
\text { the debris flow gully is in the } \\
\text { development period, but the } \\
\text { frequency is high. }\end{array}$ & Reliable \\
\hline 7 & N49 & $\mathrm{S}=0.555$ & $\begin{array}{l}\text { It is covered with mud and } \\
\text { silt by } 2.0 \text { meters on the } \\
\text { highway and harmed the } \\
\text { highway section } 350 \text { meters, } \\
\text { the harm is highly serious and } \\
\text { the debris flow gully is in the } \\
\text { development period, but the } \\
\text { frequency is high. }\end{array}$ & Reliable \\
\hline 8 & N61 & $S=0.353$ & $\begin{array}{l}\text { It is covered with mud and } \\
\text { silt by } 1.2 \text { meters on the } \\
\text { highway and harmed the } \\
\text { highway section } 150 \text { meters, } \\
\text { the harm is serious and the } \\
\text { debris flow gully is in the } \\
\text { development period, but the } \\
\text { frequency is high. }\end{array}$ & Reliable \\
\hline 9 & N63 & $S=0.495$ & $\begin{array}{l}\text { It is covered with mud and } \\
\text { silt by } 1.4 \text { meters on the } \\
\text { highway and harmed the } \\
\text { highway section } 350 \text { meters, } \\
\text { the harm is moderate serious } \\
\text { and the debris flow gully is in } \\
\text { the development period, but } \\
\text { the frequency is high. }\end{array}$ & Reliable \\
\hline 10 & N81 & $S=0.410$ & $\begin{array}{l}\text { It is covered with mud and } \\
\text { silt by } 1.5 \text { meters on the } \\
\text { highway and harmed the } \\
\text { highway section } 180 \text { meters, } \\
\text { the harm is moderate serious } \\
\text { and the debris flow gully is in } \\
\text { the development period, but } \\
\text { the frequency is high. }\end{array}$ & Reliable \\
\hline 11 & N87 & $\mathrm{S}=0.236$ & $\begin{array}{l}\text { It is covered with mud and } \\
\text { silt by } 0.8 \text { meters on the } \\
\text { highway and harmed the } \\
\text { highway section } 20 \text { meters, } \\
\text { the harm is small and the } \\
\text { debris flow gully is in the } \\
\text { development period, but the } \\
\text { frequency is high. }\end{array}$ & Reliable \\
\hline
\end{tabular}




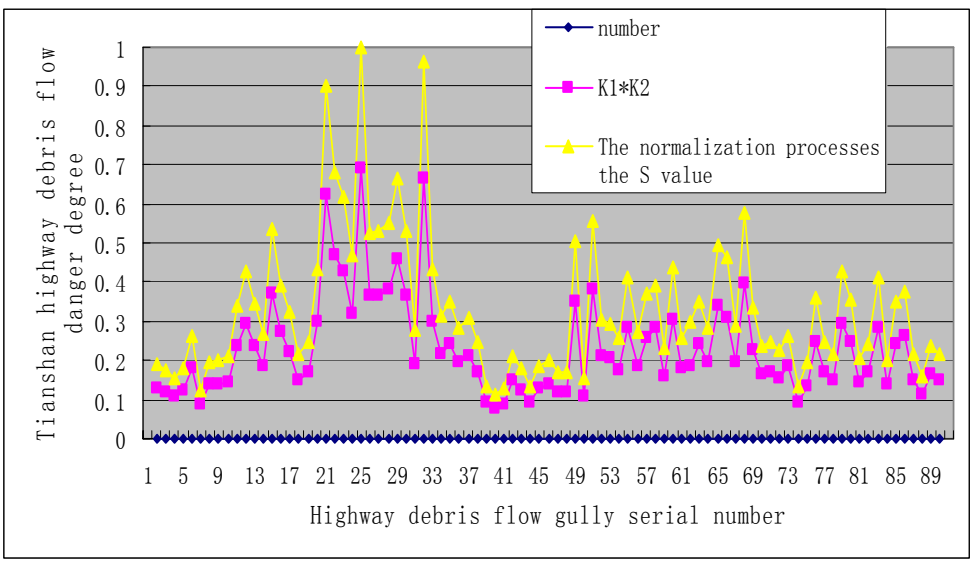

Figure 1: Tianshan highway debris flow hazard degree assessment results.

Table 6: Tianshan highway debris flow hazard degree graduation standard and prevention and control measures.

\begin{tabular}{|l|l|l|l|l|}
\hline $\begin{array}{l}\text { Highway } \\
\text { debris flow } \\
\text { hazard } \\
\text { degree }\end{array}$ & $\begin{array}{l}\text { Risk } \\
\text { assessment }\end{array}$ & $\begin{array}{l}\text { Preventing } \\
\text { and } \\
\text { controlling } \\
\text { principles }\end{array}$ & $\begin{array}{l}\text { Preventing and controlling } \\
\text { countermeasures }\end{array}$ & $\begin{array}{l}\text { Engineer- } \\
\text { ing } \\
\text { design } \\
\text { target }\end{array}$ \\
\hline$\geq 0.80$ & $\begin{array}{l}\text { Extreme } \\
\text { hazard. } \\
\text { primarily, } \\
\text { governing } \\
\text { secondly. }\end{array}$ & $\begin{array}{l}\text { Circles prevention. If it is } \\
\text { unable to circle prevention, we } \\
\text { take the early warning } \\
\text { measures. When it is necessary, } \\
\text { biology and construction } \\
\text { measures can be used together. }\end{array}$ & $\begin{array}{l}100 \text { year } \\
\text { once }\end{array}$ \\
\hline $0.50-0.80$ & $\begin{array}{l}\text { Highly } \\
\text { danger } \\
\text { hazardous. }\end{array}$ & $\begin{array}{l}\text { Guarding } \\
\text { and } \\
\text { governing } \\
\text { together }\end{array}$ & $\begin{array}{l}\text { Soft measure: prediction and } \\
\text { forecast; Hard measure: biology } \\
\text { and construction measures can } \\
\text { be used together. }\end{array}$ & $\begin{array}{l}50 \text { once year } \\
\text { once }\end{array}$ \\
\hline Moderate & $\begin{array}{l}\text { Governing } \\
\text { primarily, } \\
\text { guarding } \\
\text { secondly. }\end{array}$ & $\begin{array}{l}\text { Biology and construction } \\
\text { measures can be used together, } \\
\text { when it is necessary, } \\
\text { monitoring system can be set } \\
\text { up. }\end{array}$ & $\begin{array}{l}20 \text { year } \\
\text { once }\end{array}$ \\
\hline$\leq 0.25$ & $\begin{array}{l}\text { Mild } \\
\text { hazard. }\end{array}$ & $\begin{array}{l}\text { Guarding } \\
\text { primarily, } \\
\text { governing } \\
\text { secondly. }\end{array}$ & $\begin{array}{l}\text { Enhance the conservation of } \\
\text { water and soil and protect } \\
\text { ecological environment. }\end{array}$ & $\begin{array}{l}10 \text { year } \\
\text { once }\end{array}$ \\
\hline
\end{tabular}

3) This model and the correlation graduation assessment system may be worked as the security margin of safety design research foundation on other debris flow area highway, rail and so on.

At the same time, we also proposed suggestions as follows: 
1) To $K_{1}$ and $K_{2}$ in various factors quantitative graduation, we should consider different debris flow characteristics and carry on through the adjustment.

2) We should optimize the highway damage degree $\left(\mathrm{K}_{2}\right)$ formula further and let it be more reasonable.

\section{References}

[1] Chen Hongkai, Tang Hongmei, highway debris flow research and father, Beijing. People's transportation publishing Press, 2004. (in Chinese)

[2] Fei Peizhi, Studies the model application course, Press of Chengdu. Sichuan University, 1998. (in Chinese)

[3] Wang Yingluo, Systems engineering, Beijing. Mechanical industry publishing Press, 2003. (in Chinese)

[4] Liu Xilin, Tan Chuan, Debris flow risk assessment, [M]. Chinese Scientific Publishing Press, 2004. (in Chinese)

[5] A.Canu, G.Lorenzini, Gullies and debris flows analysis- a case study in Sardinia and a rheologicalmodelling approach, Monitoring Simulation Prevention and Remediation of Dense and Debris Flows, WIT Press, 2006.

[6] F. Wei, K. Gao, P. Cui, K. Hu, J. Xu, G. Zhang, B. Bi, Method of debris flow prediction based on a numerical weather forecast and its application, Monitoring Simulation Prevention and Remediation of Dense and Debris Flows, WIT Press, 2006.

[7] Wang Peizhuang, Fuzzy set theory and application. Shanghai Science and technology Publishing Press, 1986. (in Chinese)

[8] Tang Bangxing, Chinese debris flow, Beijing, Commercial Press, 2000. (in Chinese) 